\title{
Father's Image in Digital Short Stories in September 2018 Edition
}

\author{
Nensy Megawati Simanjuntak \\ Universitas Negeri Surabaya \\ Surabaya, Indonesia \\ nensymegawatisimanjuntak2406@gmail.com
}

\author{
Cholis Mawanti \\ Universitas Negeri Surabaya \\ Surabaya, Indonesia \\ cholismawanti@sman1wonoayu.sch.id
}

\begin{abstract}
Digital literature is literature that involves actors, perceptions, and technology as the main components. One of the digital literature that is currently in trend is a digital short story. Digital short stories are packaged in various forms, one of which is a digital application. Digital applications that focus on presenting short stories every month are applications that are owned by Kompas with the name "Lakon Hidup". In life plays various themes are presented. This study raised the theme "Father" as a zone for data acquisition. This research focuses on the representation of the figure "Father" in the digital short story "Lakon Hidup" Edition of September 2018. This research uses Greimas' proprietary study as a knife to dissect the operational and functional structures in digital short stories contained in the digital application "Lakon Hidup". Through a system of selecting data based on the theme "Father", three short stories were found. This study resulted that there were differences in representation of the figure of Ayah. Each father figure occupies a certain position in an active structure. But behind these differences there are similarities, namely the three figures in the three short stories with the theme "Father" together have a motive in the role they play. This study concluded that the figure of the father in the three short stories played a varied role. The position of the role they play is very clear in the financial structure presented in the form of a scheme. These roles are all positive.
\end{abstract}

Keywords-digital; daddy; short stories

\section{INTRODUCTION}

Representation is the result of an empirical process so that it sticks to itself and produces a real action. Representation does not only exist in the real world, representation is also born in the world of fiction. Birth of representation can be seen from the characters created by the author. Representation will bring the concept of self in view of doing something [1]. Representation is also present in the digital world. Digitalization accepts new representations for people who see themselves as digital society. Digitalization is becoming a trend in human life. All systems of life that used to be paradoxical now turn to digital. One of them is the change of the text of caste works.

Literary works that carry digital concepts are sent to the digital world through existing technology. Literary works no longer form prints, but change the form into digital files that can be enjoyed through devices or other electronic media. One of the electronic media that focuses on filling itself with literary works is "Live Life". Live play is a digital application that contains a collection that can be accessed online or downloaded through the play store. This application is published collection published by Kompas daily letter. Read short stories are short stories with the theme of life.

Short story as a work of fiction is one of the ideas to convey ideas, which is used using a unique language, because the language holds special functions, in smoothing the way of telling. The story told in a short story can depart from reality, or also an imaginary story that is discussed with reality. This study will examine three digital short stories with the theme of Father in the September 2018 edition of "Live Life". These three short stories will be dissected using Gramsci's theory [2]. Actional using structural and functional design to describe the position of the characters and the story in the short story.

Greimas [3] argues about the structure of narrative texts consisting of external and internal structures. The inner structure can be divided into two parts, namely the narrative level and the discursive level.

The researcher focused this research on the narrative level. Narrative level about narrative syntax analysis. This narrative syntax analysis can be searched in two ways, namely 2 using the actan model and functional structure.

Actant is an abstract role that is divided into six functions, namely the sender, object, subject, helper, opponent, and receiver. The sender is someone who wants something. The object is someone or something the sender wants. The subject is someone or something who managed to get the desired object. A helper is someone or something that helps the subject to get the object. Opponent is someone or something that the subject has to offer to get the object. Recipient is someone or something that receives an object. The six interrelated active functions are discussed through transfer.

The scheme is then called the actan. While the functional structure in narrativeology is A.J. Greimas is a constant road story. According to the narrator of A.J. Greimas, a story always runs from beginning to end. Therefore, the functional structure is divided into three parts, namely the initial results, transformation, and end. Transformation itself is divided into three, namely, prowess, main glass and glorious glass. This research focuses on three short stories that describe the representation of the father in his story. This study uses an actal research as a scalpel. Actional theory was agreed to support the announcement of Father's representative in the three short stories selected.

It is hoped that by using an operational scalpel, the digital short stories contained in a digital application called "Live Life" 
can be deciphered properly and sharply. Not only that, through the study, it is hoped that this research will have its own color in research that elevates digital literature as a domain for research. 2. Research Methods The method used is a descriptive qualitative research method using an actential study as a knife to describe the representation of the father figure. Retrieval of data in this study using observation techniques. The data contained in the digital application called "Lako Hidup" was chosen based on a predetermined theme namely the theme "Father". The selected data amounted to three digital short stories. The data uses the words "Father" or "Father" in the title. The selected data is a digital short story published during September 2018.

\section{METHOD}

The method used is a descriptive qualitative research method to describe the representation of the father figure. Retrieval of data in this study using observation techniques. The data contained in the digital application called "Lako Hidup" was chosen based on a predetermined theme namely the theme "Father". The selected data amounted to three digital short stories. The data uses the words "Father" or "Father" in the title. The selected data is a digital short story published during September 2018. This data was chosen because it is considered current.

\section{RESULTS AND DISCUSSION}

This research produces the following data:

A. Short Story titled "Sarong for the Father" by Rendra, September 9, 2018

\section{1) Actual Structures}

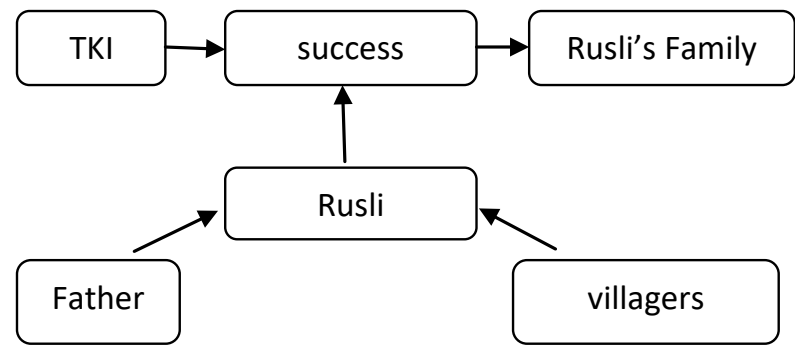

\section{2) Functional Structure}

\begin{tabular}{|l|l|l|l|l|}
\hline \multirow{2}{*}{$\begin{array}{l}\text { Early } \\
\text { Situation }\end{array}$} & \multicolumn{3}{|c|}{ Transformation } & \multirow{2}{*}{ Final Situation } \\
\cline { 2 - 4 } & Beginning & \multicolumn{1}{|c|}{ Main } & \multicolumn{1}{|c|}{ End } & \\
\hline $\begin{array}{l}\text { Rusli wants } \\
\text { to be TKI } \\
\text { in Korea. }\end{array}$ & $\begin{array}{l}\text { Villagers } \\
\text { snickered. }\end{array}$ & $\begin{array}{l}\text { Enjoy } \\
\text { success }\end{array}$ & $\begin{array}{l}\text { Can't go } \\
\text { home } \\
\text { when dad } \\
\text { dies. }\end{array}$ & $\begin{array}{l}\text { Go home and } \\
\text { crying. }\end{array}$ \\
& & $\cdot$ & & \\
& & & & \\
\hline
\end{tabular}

B. Short Story titled "Mother, Where's Dad?" Putut's Work, 30 September 2018

\section{1) Actual Structures}

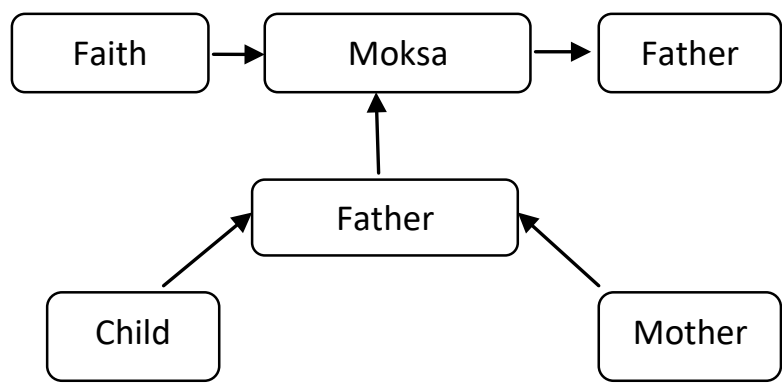

2) Functional Structure

\begin{tabular}{|c|c|c|c|c|}
\hline \multirow{2}{*}{$\begin{array}{c}\text { Early } \\
\text { Situation }\end{array}$} & \multicolumn{3}{|c|}{ Transfromation } & \multirow{2}{*}{$\begin{array}{c}\text { Final } \\
\text { Situation }\end{array}$} \\
\hline & Beginning & Main & End & \\
\hline $\begin{array}{l}\text { Perfect } \\
\text { belief in } \\
\text { God } \\
\text { (Moksa) }\end{array}$ & $\begin{array}{l}\text { Never pray in } \\
\text { congregation. }\end{array}$ & $\begin{array}{l}\text { Do not use } \\
\text { religious } \\
\text { propositions } \\
\text { in educating. }\end{array}$ & $\begin{array}{l}\text { Do not } \\
\text { believe in } \\
\text { the } \\
\text { existence of } \\
\text { heaven and } \\
\text { hell. }\end{array}$ & $\begin{array}{l}\text { Come } \\
\text { back to } \\
\text { God. }\end{array}$ \\
\hline
\end{tabular}

C. Short Story entitled "Dead Dog in Father's Head" by Budiono, 30 September 2018

1) Actansial Structures

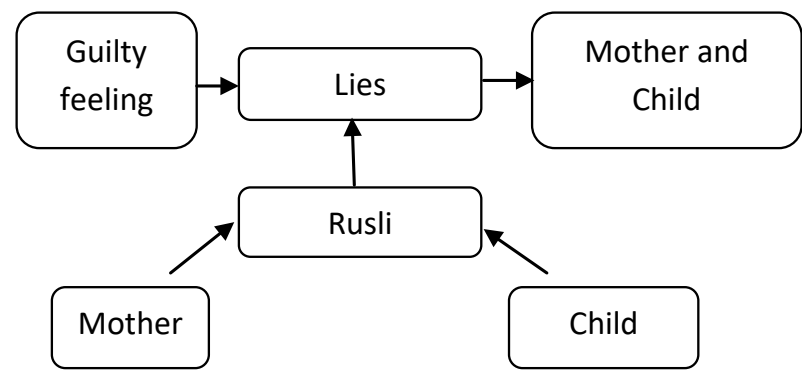

2) Functional Structure

\begin{tabular}{|c|c|c|c|c|}
\hline \multirow{2}{*}{$\begin{array}{c}\text { Early } \\
\text { SItuation }\end{array}$} & \multicolumn{3}{|c|}{ Transfromation } & \multirow{2}{*}{$\begin{array}{r}\text { Final } \\
\text { Situation }\end{array}$} \\
\hline & Beginning & Main & End & \\
\hline $\begin{array}{l}\text { Father's anger } \\
\text { at each dog's } \\
\text { carcass is } \\
\text { called. }\end{array}$ & $\begin{array}{l}\text { Revenge } \\
\text { children for } \\
\text { being hit by } \\
\text { Dad. }\end{array}$ & $\begin{array}{l}\text { Children } \\
\text { feel } \\
\text { curious } \\
\text { and } \\
\text { addicted. }\end{array}$ & $\begin{array}{l}\text { Mother told } \\
\text { me why } \\
\text { Dad hates } \\
\text { dog } \\
\text { carcasses. }\end{array}$ & $\begin{array}{l}\text { Dad is } \\
\text { honest } \\
\text { about his } \\
\text { anger. }\end{array}$ \\
\hline
\end{tabular}




\section{CONCLUSION}

This study concludes that the representation of the father's characters in short stories contained in digital applications can be seen through the role that brought the character's father in the story. Every father's role in the three short stories has a motive in the actions that the character's father actualizes. Father in the first short story acts as a helper or support for his child. The father figure in the second story believes to be immoral in his life. Father in the third short story forced to lie because he is the cause of death of his father-in-law. His father-in-law died and his body floated along with the dead dog.

\section{REFERENCES}

[1] D. Susanto, Pemgantar Teori Sastra (Dasar-Dasar Memahami Fenomena Kesusastraan: Psikoanalisis Sastra, Struturalisme, Formalisme Rusia, Marxisme, Interpretasi dan Pembaca, dan Pascastrukturalisme. Yogyakarta: CAPS, 2012.

[2] P. Ives, Language and Hegemony in Gramsci. London: Pluto Press, 2004.

[3] A.J. Greimas, “Actants, Actors, and Figures.” On Meaning: Selected Writings in Semiotic Theory. Minneapolis: University of Minnesota, 1987. pp. 106-120. 